\title{
The Study of Motivation in Library and Information Management Education: Qualitative and Quantitative Research
}

\author{
Carmen Pérez-Sabater and Begoña Montero-Fleta \\ Universitat Politècnica de València, Valencia, Spain
}

\author{
cperezs@idm.upv.es; bmontero@idm.upv.es
}

\author{
A motivated learner is eager to learn the \\ language, willing to expend effort on the learning \\ activity, and willing to sustain the learning activity
} (Gardner, 1985:10).

\section{Executive Summary}

The application of new technologies and media has changed the concept of teaching and learning, offering effective and attractive possibilities to the educational system, particularly to the learning of languages in specific contexts. Educators in general will agree on the importance of motivation as a key to success in language acquisition as it is both a condition and a result of effective instruction. However, although research has recognized the positive effect of intrinsic motivation on learning and academic achievement, little is known about the impact of different technologysupported learning activities on students' intrinsic motivation, the most critical factor for success in language teaching through computers according to some scholars.

In this paper we present a university course project carried out in the English class in a degree of Library and Information Management. By means of an integrated analysis which includes qualitative and quantitative research, we see the influence of a CMC (Computer-mediated Communication) genre, that of weblogs, in learning, and the way this new learning environment enhances motivation. In the project we present, students were asked to participate in blogs dealing with topics of their field of studies, a fact that constitutes the authentic learning environment suggested by some scholars in the field of education. Blogging was the key activity of their writing course. Students' participation in blogs implied exchanging posts, making comments, agreeing and disagreeing on what was discussed in the posts, asking for clarification, etc., always with the hope of raising the interest of other bloggers and starting a discussion.

Questionnaires administered to the students and interviews have provided insightful data to the research about the students' perception of the experience, in other words, their levels of involvement in learning, their engagement in efficient and creative thinking processes, and their use of

Material published as part of this publication, either on-line or in print, is copyrighted by the Informing Science Institute. Permission to make digital or paper copy of part or all of these works for personal or classroom use is granted without fee provided that the copies are not made or distributed for profit or commercial advantage AND that copies 1) bear this notice in full and 2) give the full citation on the first page. It is permissible to abstract these works so long as credit is given. To copy in all other cases or to republish or to post on a server or to redistribute to lists requires specific permission and payment of a fee. Contact Publisher@InformingScience.org to request redistribution permission. problem-solving strategies. Language achievement tests as well as daily one minute papers supplied information on the students' acquisition of the content dealt with.

The innovative approach of this research is that it has allowed students to participate in real-world environments: blogs where students were able to apply theoretical knowledge acquired in the degree of Information and Management Educa- 
tion in the medium of English. Writing for a purpose, a truly novel component of the educational application of blogs used in the present project has resulted in a positive attitude of the students and, thus, has enhanced motivation.

Keywords: motivation, language learning, computers for education, Library and Information Management Education

\section{Context}

The term Computer-mediated Communication (CMC) was coined at the end of the 1970's by Hiltz and Turoff (1978); at that time, its use was restricted to computer conferencing. CMC evolved and meant different things to different people. But in 1996, with the edition of a specialized manual entitled Computer-mediated communication: Linguistic, social and cross-cultural perspectives, most scholars seem to agree with Herring's (1996) proposal: "CMC is the communication that takes place between human beings via the instrumentality of computers" (p. 1). D. E. Murray (2000) modifies communication to include only text-based modes, eliminating uses of computer technology that do not imply communication, such as video games. In Herring (2001) the term is nuanced again to include only "the communication produced when human beings interact with one another by transmitting messages via networked computers" (p. 612). Recently, Baron (2008) talks about Electronically-mediated Communication (EMC) in order to incorporate texts sent through cell phones. In this paper, we will follow Herring's (2001) premises about $\mathrm{CMC}$ to refer to texts exchanged through computers.

The study of Computer-mediated Communication Discourse has implied studies involving qualitative or quantitative research (or a combination of both) during the last two decades. An example of a purely quantitative analysis is the comparison of a corpus of computer conferencing messages with written and spoken corpora carried out by Yates (1996), while an example of the qualitative approach to CMC would be the ethnographic study by Kendall (2002) concerning gendered behaviour in a Multi User Dimension (MUD). Herring (1996) applied both approaches in her study of email messages. The evolution of writing described by Baron (2000) is, in our opinion, the most exhaustive study about CMC up to date; in this book, Baron underlines the hybrid nature of CMC: a mixture of oral and written discourse.

In a previous paper (Montero-Fleta \& Pérez-Sabater, 2011), we claimed that the application of new technologies and media to the specific context of Library and Information Management has broadened the concept of teaching and learning, offering effective and attractive possibilities to the educational system, particularly to the learning of languages. In this paper, we present a course project which incorporates a fairly recent subgenre of CMC, that of weblogs, more commonly called blogs, to English language learning. We will see if the application of this new technology is attractive and effective to our students and, thus, enhances motivation in the language classroom, despite the results of some scholarly research which show the drawbacks of the incorporation of computers in existing teaching formats.

\section{The Use of Blogs in Educational Settings}

A blog has been defined as "a web application that displays serial entries with date and time stamps" (Thorne \& Payne, 2005, p. 381). Blogs often include a comments feature which allows the reader to engage in discussion with the blog's writer and other readers by directly attaching a post to the daily or topical entry (Radzikowska, 2003). It is important to point out that any post sent to a blog can be modified by the blog's writer, that is, a post is sent first to the blog and its writer decides its publication. The blog's writer has the power of publishing it and can also modify it before $\mathrm{s} /$ he includes it in the blog. 
Getting involved in blogs, i.e., blogging, has become a recent phenomenon from a sociological standpoint (Montes-Alcalá, 2007), useful not only for dissemination of information, for communication, and for reflection but also for providing teachers and learners with multiple possibilities to enhance their daily practice due to the multimedia features and interactivity involved. According to Huffaker (2005), "In the classroom, students can have a personal space to read and write alongside a communal one, where ideas are shared, questions are asked and answered and social cohesion is developed" (p. 94).

In language learning, L. Murray, Hourigan, and Jeanneau (2007) claim that the teacher's main challenge when using blogs is to create meaningful activities in the language learning classroom. For Pinkman (2005), blogs can be used as tools to develop writing skills and, although they should not replace face-to-face interaction, they may provide a practice environment where students can think, reflect, and create language slowly for a real-life audience.

In this context, the major benefits of blogging in the language classroom have been reported as "the choice of more appropriate language on the part of the learners, the addition of new perspectives to the learners' thoughts, and the motivational aspect of realizing that one's voice echoes in distant parts of the globe and is heard by others" (Arena, 2008, p. 4). Sun's findings (2009) suggest that blogs can constitute a dynamic forum that fosters extensive practice, learning motivation, authorship, and development of learning strategies. The added value of using blogs means that students produce contents that are instantly accessible on the web, which can potentially attract comments from other users, whether they are classmates or anonymous bloggers (L. Murray, et al., 2007).

On the other hand, in other learning contexts, some researchers complain about the fact that the generalized use of web technologies in the classroom may have some drawbacks (Cole, 2009), since the incorporation of technology enhanced learning activities needs a sound pedagogical approach to be an effective learning tool. This new learning approach implies a radical change in the learning paradigm applied so far (Cole, 2009; Hadjerroui, 2011). As Coldwell, Craig, \& Goold (2011) propose, the challenge for the modern educator then is to "engage a diverse range of students using an ever increasing range of eTechnologies now available (and remain sane through the process)" (p. 97).

\section{Motivation and Language Learning Achievement}

As far as motivation is concerned, it has been reported as the most critical factor for success in language teaching through computers (Ushida, 2005). Educators in general will agree on the importance of motivation as a key to success in language acquisition as it is both a condition and a result of effective instruction (Winne \& Marx, 1989).

Theories of language acquisition have considered external factors, i.e., input and social aspects, internal factors, i.e. cognitive, sociocultural and linguistic, as well as affective factors, all of them affecting second language acquisition (see Ellis, 1997). The study of motivation in the language classroom reached an exciting turning point in the 1990s, resulting in what Gardner and Tremblay (1994) called a 'motivational renaissance'. Motivation has become central to a number of theories of second language (L2) acquisition, and a number of motivation models have been postulated (e.g. Clément 1980; Gardner 1985; Krashen 1981; Spolsky, 1985; Ushioda, 2008). Motivation has been defined as the activation or goal-oriented behaviour, i.e., what moves a person to make certain choices, to engage in action, and to persist in action (Ushioda, 1996). The concept of motivation, previously used in the realm of psychology, has been transferred to the field of education, or rather, to the field of educational psychology concerned with how students learn, the approaches to which they best react, and ultimate rates of success. 
Social and educational psychologists distinguish between intrinsic and extrinsic motivation. Extrinsic motivation implies doing something as a means to some separable outcome such as getting a job or gaining a qualification (Ryan \& Deci, 2000). In contrast, intrinsic motivation, i.e., doing something as an end in itself, is closely related with the learners' enjoyment, interest, challenge in skill, and knowledge development, and results in high quality learning and creativity.

Ryan and Deci (2000) claim that many of the tasks that educators want their students to perform are not inherently interesting or enjoyable; thus, in this context, an essential strategy to enhance learning is to promote more active and volitional forms of activities to increase motivation. Additionally, these authors highlight the spontaneous learning behaviour and powerful self-sustaining dynamics of intrinsic over extrinsic motivation which leads to a qualitative difference and a more effective kind of learning. In their words, Deci and Ryan (1980) suggest (as cited in Ushioda 2008, p. 21): "Intrinsically motivated learners are deeply concerned to learn things well, in a manner that is intrinsically satisfying and that arouses a sense of optimal challenge appropriate to their current level of skill and competence". Moreover, other researchers such as Parker (2003) consider the study of intrinsic motivators of greater importance than extrinsic motivators in education. Consequently, having this perspective in mind, in this paper we will mainly centre on the study of intrinsic motivation in language learning.

\section{Justification for the Study}

Nowadays, CMC is common practice in education, particularly in tertiary education. Nevertheless, as some scholars have argued, the application of this technology in some fields, such as language learning in specific contexts, is in need of more research (Kuteeva, 2011). On the other hand, based on scholarly research as a point of departure of our study, we assume that motivation may be an important factor for successful computer technologies in the language class. Research has recognized the positive effect of intrinsic motivation on learning and academic achievement; however, Shroff, Vogel, and Coombes (2008) believe that little is known about the impact of different technology-supported learning activities on students' intrinsic motivation. In this line, in a study about the use of blogs in the English classroom, Blackstone, Spiri, and Naganuma (2006) posit that students' motivation increases when they participate in meaningful writing activities, which is translated into greater and higher quality production. Blogging in language learning can contribute to more fruitful interaction among classmates and the teacher; it can extend instruction beyond the university walls as blogs allow participants to be "together at any time and place" (Arslan \& Sahin-Kýzýl, 2010, p. 194) and, hence, contribute to the increase of interest in these tasks. In fact, it is interesting to underline that the extra time taken by these activities outside the school time wouldn't be possible without the motivational factor of blogging for language learners (Arslan \& Sahin-Kýzýl, 2010). In our case, we will focus on the use of blogs to enhance motivation in language learning in the specific context of tertiary students in the degree of Library and Information Management. In the line of Connolly and Stansfield (2006), we believe that online learning can make a major contribution to the educational requirements in teaching Information Management- related concepts.

\section{Aim and Hypotheses of the Study}

The objective of the course project presented was to study the motivation of university students of English for Library and Information Management following a methodology based on their participation in professional blogs as the key activity of their writing course carried out in 2010. In this paper, we describe the students' perception of the experience, in other words, their levels of involvement in learning, the students' engagement in efficient and creative thinking processes, their use of problem-solving strategies, and the interaction and effective knowledge of the content studied. Thus, our main hypothesis is that students engaged in blogs in authentic environments 
dealing with their specific field of study are motivated in their English writing course and their learning outcomes are better than in previous years, in spite of the problems that computer enhanced learning may pose to students' engagement. A comparison with the results obtained in the same subject in the previous course 2009 will be provided in some aspects of this research, following Shroff et al. (2008). In 2009, students who followed this subject did not participate in any technology enhanced project.

\section{Methodology}

\section{Sample Population}

The experiment was run in a group of 32 students of English writing in a Spanish university degree in Library and Information Management over the course of a semester. The average age of the students was 22.8. The group was formed by 24 male students and 8 female from different backgrounds: 20 Spanish students, 8 Erasmus from several European countries, and 4 students whose parents are immigrant from Ecuador and China (the imbalance between men and women observed, although of scholarly interest, is out of the scope of this research). Students had a wide range of language proficiency levels. They were experienced in the use of new technologies.

Classes met 3 hours a week. This group was chosen because the sample reflects the current cultural and linguistic diversity of higher education in Spain: a high percentage of Erasmus students per class and the first students from an immigrant origin arriving at university, a culturally heterogeneous learning environment similar to universities worldwide (Kim, 2008). The classroom profile of our experiment is similar to previous courses and the results can be extrapolated to them and to future learning environments (Staehr \& Byrne, 2011).

The subject English writing is taught in the fourth year of the degree in Library and Information Management. The objective of the course is to develop not only fluency but also accuracy, quality, and correctness in writing in English. In 2010, up to this point in their studies, the students had mainly received instruction in the traditional face-to-face format. The students had never had the chance of using the language in an authentic environment, i.e., environments that provide an authentic context that reflect the way the knowledge will be used in real life (Herrington \& Herrington, 2005). In this project, the cognitive authenticity implied in the students' participation in blogs dealing with topics of their field of studies constitutes the authentic learning environment suggested by Herrington and Herrington (2005).

Finally, we should mention that the authors of the study have been the teachers of the subject during the last ten years, so the accessibility to the study and data from former courses is complete.

\section{The Experiment}

In order to frame class blogs within an authentic context, students were provided with a list of 150 blogs for Library Science where a world of information specific to their field of study is available and discussed. Following Farmer (2004), we chose blogs that enabled comments and could generate discussions because of the novelty of the issues, sometimes even controversial, dealt with, i.e., blogs that could be a medium to effectively facilitate the successful formation of a community of inquiry. Students got engaged in the required assignments, which consisted in participating in blogs: exchanging posts, making comments, agreeing, and disagreeing on what was discussed in the posts, asking for clarification, etc., always with the hope of raising the interest of other bloggers and starting a discussion. As part of the writing tasks, on a weekly basis students were required to dedicate an hour in groups to elaborate on the posts and to respond in class. In parallel, students daily checked their blogs and followed the thread of the discussions in the blogs outside the English classroom, either at home or in the computer room. 
Table 1 summarizes the profile of the students involved and their performance:

\begin{tabular}{|c|c|}
\hline \multicolumn{2}{|c|}{ Table 1: Group profile and language output } \\
\hline Number of participants & 32 \\
\hline Language level & 10 Lower Intermediate \\
\hline & 16 Upper Intermediate \\
\hline & 6 Advanced \\
\hline Number of posts sent & 80 \\
\hline Average number of words per post & 70 \\
\hline Total number of words in posts & 5600 \\
\hline Average number of words per portfolio & 2000 \\
\hline
\end{tabular}

The teacher's attitude towards the activity plays a primary role in the success of the experiment as some of her/his enthusiasm will be transmitted to the students, who will be more likely to become interested in the tasks being carried out. Therefore, teachers explained in detail what was expected on the activities and how blogs worked, insisting on the versatility of the tool. Moreover, some introductory tutorials on collaborative work, formal writing focusing on paragraph structure and coherence, and blog interaction were devised. These tutorials were carried out in the first week of the semester and included information about ethics on team work so as to involve members in an equal contribution of the work, the use of formal vs. conversational writing, and an analysis of the comments exchanged in the thread of a blog, taken as an example, so as to familiarise students with the tool and value the style used and the quality of contributions.

\section{Quantitative and Qualitative Analysis}

To study motivation, an integrated methodology was put into practice. This implied a combination of quantitative and qualitative data collection. Quantitative research consisted in the measurement of students' course participation by recording class attendance, homework submission, and participation in learning activities. In parallel to the quantitative study, a qualitative study on the students' background, attitudes, and motivation was carried out. In Creswell's (1998) words, qualitative research is "an inquiry process of understanding" where the researcher elaborates a "complex, holistic picture, analyzes words, reports detailed views of informants, and conducts the study in a natural setting" (p. 15). Thus, data were collected from a questionnaire with open questions which was administered at the beginning and end of the semester to provide feedback from the learner's perspective. The questionnaire was distributed in the second class and the week before the final class in order to identify changes over time; all participants completed it. The experiment also included the teacher observation in the classroom. Our initial idea of administering questionnaires on a monthly basis to provide more feedback was discarded because students are often reluctant to answer repetitive questions on the same issue. Consequently, we considered that these two questionnaires could provide enough fruitful information for the study. Moreover, they were complemented by abundant interviews throughout the semester. All students were individually interviewed to provide feedback from their perspective on their perceived interest, challenge, difficulty, and on their intrinsic motivation (enjoyment, sense of challenge, skill development). The rationale for the interview questions was to gather information. The transcriptions of the interviews and the students' reflections on the portfolios were organized, categorized, interpreted and synthesized. The subsequent analysis allowed us to cluster data into two meaningful categories: the blogging process and language improvement. 


\section{Results and Discussion}

What can be drawn from the analysis is that students in the project showed a highly favourable reaction to the experience and related motivation with language achievement and behavioural outcomes such as classroom participation or persistence in learning, a positive result that is not always found in web-based learning environments in tertiary education (Cole, 2009).

As aforementioned, the qualitative part of our analysis clustered data into the following meaningful categories:

a) The blogging process: students' motivation correlates strongly with their perception of appropriate level, content interest, and ease of use, as suggested, following Kurt Lewin's basic concept of 'level of aspiration', in Montero-Fleta et al.(1999). Data have been organised in Appendix A for clarification.

Firstly, it is interesting to point out that most students agreed on the fact that the level of the tasks carried out was appropriate.

Secondly, interviews also showed that the group's high motivation was enhanced by their active engagement in authentic communication in their field of studies in English and their participation in a social network based on their professional interests. Participants were satisfied at being able to express themselves freely, a clear parameter that enhances intrinsic motivation in technology supported activities according to Shroff et al. (2008). Students also favoured being able to express their opinions more comfortably, avoiding stress, and being able to improve their thinking abilities. Besides, they enjoyed dealing with topics related to their future career, being involved in authentic communication, reflecting on ideas and giving feedback to classmates' entries. They affirmed that being assessed by other professionals of information management had been rewarding, participating in class discussion had been interesting, and collaborative work productive. Participants were kept excited when trying to communicate reflections on knowledge recently acquired in the specific subjects of their studies and when expressing their opinions on the posts exchanged with other students, and the feedback sent from the blog.

Likewise, their motivation to participate in the blogging process correlates highly with the time dedicated to the activity outside the language class (Arslan \& Sahin-Kýzýl, 2010). On average, students spent an extra hour per week on the activity, a clear parameter to measure students' interest. Since they devoted a lot of time and energy to getting feedback, they felt greatly motivated at the reception of an answer to their comment and complained when they got zero reactions from the audience. Sometimes, they felt that too much time and effort was being put in with the only hope of getting a response, an important motivational factor in online communication through blogging (Kim, 2008). Despite some drawbacks, students often justified the lack of feedback from other bloggers in the written portfolios and tried to transmit a positive side of their learning experience. When students were pleased with their efforts, they invested more time in the task, a similar outcome to the results of the experiment carried out by Shroff et al. (2008).

Finally, as can be seen in Appendix A, ease of use was also considered a positive motivational factor by students.

The following opinions are representative examples of the whole classroom perception. An Erasmus student, Aurelien, explained the advantages of this learning experience: "It is interesting to exchange opinions and points of view not only with classmates but also with people all over the world, always in English" (the examples are shown in the original; students explicitly agreed on the use of the data obtained in the study for research and dissemination of results). However, some students were disappointed when they didn't receive an answer to their posts: Miguel, a Spanish student, commented, “After my experience I don't believe too much in the blogs and the interaction with them, at least with the blogs from over the ocean". In this concern, Marta, a 
Spanish female, complained that although the activity was really encouraging, the fact that they didn't receive many responses to their posts was a bit disappointing. Her opinions about the activity changed when she started to write more aggressively and disagreed with other bloggers; then, more answers to her posts arrived and she could express herself. As for the extra time taken, René, an Erasmus student, commented that he enjoyed getting involved in the threads so much that he dedicated some of his free time to the activity.

Students felt intrinsic motivation in being able to participate in the "English-dominated on-line world"; they felt inherent satisfaction in doing the activity which has moved them "to act for the fun or challenge" (Ryan \& Deci, 2000, p. 56). The students' positive attitude towards Internet activities confirmed that intrinsic motivation occurred because of its appeal of novelty, challenge or aesthetic value that Ryan and Deci consider critical in raising students' motivation, and what's more, they appeared to retain their positive motivation over the 14-week semester.

b) Language improvement: another factor studied was the students' own perception of their improvement in language skills. Data have been clustered in Appendix B.

When posting blogs, students were mostly concerned in using the English language accurately. Students strongly agreed on the fact that their writing fluency, grammar accuracy as well as correct use of vocabulary had increased as they spent a long time writing their texts in order to produce attractive posts to raise attention from other bloggers. Online participation may entail a more proficient use of the language as regards non-native speakers of English. The fact that their language level could be judged by the whole online community may force students to write more carefully when participating in the blogosphere, as Montero-Fleta (in press) observed. This extra effort was not always welcomed by all the participants; in the interviews, students with a low level of English complained about the amount of effort involved in the activities. Relatedly, the teacher's perceptions of the language outcomes of the students also corroborated the improvements in their writing skills. These quantitative data of the experiment were obtained from different sources: Firstly, the use of the one-minute-paper carried out at the end of every class, as well as opening a line of communication with the students, helped them carry out an individual writing task through which the teacher could assess their improvement. The variables measured were simple sentences, words in complete sentences, word order, connectors, verb tenses, punctuation marks, and spelling on the one hand, and paragraph structure, coherence, and argumentation, on the other. Secondly, we considered the results of a test administered at the end of the course, a common practice in Spanish universities. In this test, students were required to write an essay. They were assessed on their ability to communicate ideas clearly and concisely in writing. The evaluation was based on the degree to which each essay addressed the writing task effectively and insightfully, was well organized in paragraphs with ideas fully developed, was appropriate in style and tone, and showed the students' competence in grammar, syntax, vocabulary, punctuation, and spelling.

This test showed good results in writing fluency, accuracy, overall text organization, and in grammar use: the grades of the final test were $16.2 \%$ higher than those obtained in previous courses. While in 2009 the average grade was 6.2 out of 10, in 2010 the mean grade obtained in the final exam was 7.2. Secondly, another revealing fact is that the students' level of achievement, measured annually by the university teaching board, also manifested this improvement: in 2009 the level of achievement of this subject was $67.74 \%$, implying that this percentage of students passed the subject. In 2010, the level of achievement was $86.21 \%$. These positive outcomes are similar to those obtained by Kuteeva (2011) in her study of writing proficiency in English for Academic Purposes through wikis. Finally, class attendance was higher than usual as well; it increased by $20 \%$. In the previous year, class attendance was $40 \%$ on average, while in $2010,60 \%$ of the students attended regularly. 
It is noteworthy that these results coincide with some studies on motivation and computer assisted language learning, which report that to initiate discussion on the web motivates students more than teacher-initiated discussion. Students also produce more output and the learning results tend to be better (see, for example, Jogan, Heredia, \& Aguilera, 2001). Fageeh (2011), in this concern, has pointed out that writing for both a local and a global audience has had a positive effect on his students' positive attitude towards the incorporation of blogs in language learning, it has allowed students to give vent to their emotions and ideas in cyberspace. In our case, the use of social networking in authentic environments was an additional value to the students' engagement in their learning task, which may have favoured their high levels of motivation, a difficult issue in integrating the computer in an existing teaching format according to some scholars (e. g. Cole, 2009).

Qualitative research does not always show the general results quantitative research often shows. However, in this project, students agreed on the fact that writing for a purpose had been very motivating and they valued the opportunity to develop writing skills in a real environment. Harris (1991) reaffirms this idea when he suggests that:

Students will be much more committed to a learning activity that has value for them, that they can see as meeting their needs, either long term or short term. They will, in fact, put up with substantial immediate unpleasantness and do an amazing amount of hard work if they are convinced that what they are learning ultimately meets their needs.

Nevertheless, although these activities can be very motivating for language learners, we share Warschauer's (2000) opinion when he affirms that:

The Internet does not constitute or prescribe a particular teaching method; rather, it is an important new medium bringing together tens of millions of people throughout the world. The existence of the Internet provides the potential for purposeful, powerful use of online communication in language and writing classes. It is up to us to give life to that purpose and thus achieve the full potential of computer networks in second language teaching. (p. 57)

\section{Conclusions}

New technologies such as blogging can help to overcome the difficulties involved in keeping motivation in the second language classroom. The innovative contribution developed by the project was the challenge of participating in real-world environments, blogs where students were able to apply theoretical knowledge acquired in the degree in the medium of English. This truly novel component of educational application of blogs used in the present approach has resulted in a positive attitude of the students and, thus, motivation enhancement.

Our future research will focus on the teacher's role. Future studies could also examine the role of extrinsic motivation in language learning. Moreover, as observed in the sample population of this study, the scarcity of women in technology education is a problem in our university and in Western tertiary education (Cronin \& Roger, 1999; C. Pérez-Sabater \& M. L. Pérez-Sabater; in press). In this concern, future research can address the imbalance noted and its implications in language learning in the specific context of Library and Information Management studies.

On balance, in the course project described, new values are put into practice; as far as the students are concerned, the approach entails a more challenging learning situation as they have to adapt their learning to a new social and professional environment in which they must get an answer to their posts in their effort to participate in their professional community. Students' enthusiasm and fun are translated into higher levels of motivation, which in turn have a positive effect on their academic results. It is also interesting to point out that, although the Internet embodies high and strong values such as equality of access, public service and empowerment of the individual, the 
fact that the posts can be modified by the blog's writer has made students aware of the dangers of believing everything they read on the Internet.

\section{Acknowledgements}

We would like to thanks the anonymous reviewers for their insightful comments on earlier drafts of this paper. We would also like to congratulate the editorial board of the JITE for their diligent work.

\section{References}

Arena, C. (2008). Blogging in the language classroom: It doesn't simply happen. TSEL-EJ. Teaching English as a Second or Foreign Language, 1(4).

Arslan, R. S., \& Sahin-Kýzýl, A. (2010). How can the use of blog software facilitate the writing process of English language learners? Computer Assisted Language Learning, 23(3), 183-197.

Baron, N. S. (2000). Alphabet to email. London: Routledge.

Baron, N. S. (2008). Always on: Language in an online and mobile world. Oxford: Oxford University Press.

Blackstone, B., Spiri, J., \& Naganuma, N. (2006). Blogs in English language teaching and learning: Pedagogical uses and student responses. Reflections on English Language Teaching, 6(2), 1-20.

Clément, R. (1980). Ethnicity, contact and communicative competence in a second language. In H. Giles, W. P. Robinson, \& P. Smith (Eds.), Language: Social Psychological Perspectives (pp. 147-54). Oxford: Pergamon Press.

Cole, M. (2009). Using wiki technology to support student engagement: Lessons from the trenches. Computers \& Education, 52, 141-146.

Coldwell, J., Craig, A., \& Goold, A. (2011). Using etechnologies for active learning. Interdisciplinary Journal of Information, Knowledge, and Management, 6, 96-106.

Connolly, T., \& Stansfield, M. (2006). Using games-based eLearning technologies in overcoming difficulties in teaching information systems. Journal of Information Technology Education, 5, 459-475. Retrieved from http://www.jite.org/documents/Vol5/v5p459-476Connolly170.pdf

Creswell, J. W. (1998). Qualitative inquiry and research design. Choosing among five traditions. Thousand Oaks, CA: Sage.

Cronin, C., \& Roger, A. (1999). Theorizing progress: Women in science, engineering, and technology in higher education. Journal of Research in Science Teaching, 36(6), 637-661.

Deci, E. L. \& Ryan, R. M. (1980). The empirical exploration of intrinsic motivational processes. In L. Berkowitz (Ed.), Advances in experimental social psychology: Vol. 13. (pp. 39-80). New York: Academic Press.

Ellis, R. (1997). Second language acquisition. Oxford: Oxford University Press.

Fageeh, A. I. (2011). EFL learners' use of blogging for developing writing skills and enhancing attitudes towards English learning: An exploratory study. Journal of Language and Literature, 2(1), 31-48.

Farmer, J. (2004). Communication dynamics: Discussion boards, weblogs and the development of communities of inquiry in online learning environments. In R. Atkinson, C. McBeath, D. Jonas-Dwyer, \& R. Phillips (Eds.), Beyond the comfort zone: Proceedings of the 21st ASCILITE Conference (pp. 274283). Retrieved from http://www.ascilite.org.au/conferences/perth04/procs/farmer.html

Gardner, R. C. (1985). Social psychology and language learning: The role of attitudes and motivation. London: Edward Arnold. 
Gardner, R. C. \& Tremblay, P. F. (1994). On motivation: Measurement and conceptual considerations. Modern Language Journal, 78(4), 524-527.

Hadjerroui, S. (2011). A collaborative writing approach to wikis: Design, implementation, and evaluation. Issues in Informing Science and Information Technology, 8, 431-449. Retrieved from http://iisit.org/Vol8/IISITv8p431-449Hadjerrouit224.pdf

Harris, R. (1991). Some ideas for motivating students. Retrieved from http://www.virtualsalt.com/motivate.htm

Herring, S. C. (1996). Two variants of an electronic message schema. In S. C. Herring (Ed.), Computermediated communication: Linguistic, social and cross cultural perspective (pp. 81-106). Amsterdam and Philadelphia: John Benjamins.

Herring, S. C. (2001). Computer-mediated discourse. In D. Schiffrin, D. Tannen, \& H. Hamilton (Eds.), Handbook of discourse analysis (pp. 612-634). Oxford: Blackwell.

Herrington, A., \& Herrington, J. (2005). What is an authentic learning environment? In A. Herrington \& J. Herrington (Eds.), Authentic learning environments in higher education (pp. 1-14). Idea Group Inc.

Hiltz, S. R., \& Turoff, M. (Eds.) (1978). The network nation: Human communication via computer. Reading, MA: Addison-Wesley.

Huffaker, D. (2005). The educated blogger: Using weblogs to promote literacy in the classroom. $A A C E$ Journal, 13(2), 91-98.

Jogan, M. K., Heredia, A. H., \& Aguilera, G. M. (2001). Cross-cultural e-mail: Providing cultural input for the advanced foreign language student. Foreign Language Annals, 34(4), 341-346.

Kendall, L. (2002). Hanging out in the virtual world. Berkeley, CA: University of California Press.

Kim, H. (2008). The phenomenon of blogs and theoretical model of blog use in educational contexts. Computers \& Education, 51(1), 1342-1352.

Krashen, S. (1981). Second language acquisition and second language learning. Oxford: Pergamon Press.

Kuteeva, M. (2011). Wikis and academic writing: Changing the writer-reader relationship. English for Specific Purposes, 30(1), 44-57.

Montero-Fleta, B. (in press). Looking beyond linguistic outcomes: active learning and professional competencies in higher education. Procedia.

Montero-Fleta, B., \& Pérez-Sabater, C. (2011). Knowledge construction and knowledge sharing: A wikibased approach. Procedia, 28, 622-627.

Montero-Fleta, B, Pérez-Sabater, C., Gil-Salom, L., Pérez-Guillot, C., Soler-Monreal, C., \& Turney, E. (1999). Evaluating multimedia programs for language learning: A case study. Recall, 11(3), 50-57.

Montes-Alcalá, C. (2007). Blogging in two languages: Code-switching in bilingual blogs. In J. Holmquist, A. Lorenzino, \& L.I. Sayahi (Eds.), Selected Proceedings of the Third Workshop on Spanish Sociolinguistics (pp. 162-170). Somerville, MA: Cascadilla Proceedings Project.

Murray, D. E. (2000). Protean communication: The language of computer-mediated communication. Tesol Quarterly, 34(3), 397-421.

Murray, L., Hourigan, T., \& Jeanneau, C. (2007). Blog writing integration for academic language learning purposes: Towards an assessment framework. Ibérica, 14, 9-32.

Parker, A. (2003). Motivation and incentives for distance faculty. Online Journal of Distance Learning Administration, 6(3). Retrieved from http://www.westga.edu/ distance/ojdla

Pérez-Sabater, C. \& Pérez-Sabater, M. L. (2012). A simulation for closing the gender gap intechnology education. Paper presented at the $4^{\text {th }}$ annual International meeting of the Thai Simulation and Gaming Association, Thailand, April 2012.

Pinkman, K. (2005). Using blogs in the foreign language classroom. The JALT CALL Journal, 1(1), 12-24. 
Radzikowska, M. (2003). Conversation by blog: Expanding personal technology into the academic community. Retrieved from http://citeseerx.ist.psu.edu/viewdoc/download?doi=10.1.1.199.6385\&rep=rep1\&type $=$ pdf

Ryan, R. M., \& Deci, E. L. (2000). Intrinsic and extrinsic motivations: Classic definitions and new directions. Contemporary Educational Psychology, 25, 54-67.

Shroff, R. H., Vogel, D. R., \& Coombes, J. (2008). Assessing individual-level factors supporting student intrinsic motivation in online discussions: A qualitative study. Journal of Information Systems Education, 19(1), 111-126.

Spolsky, B. (1985). Formulating a theory of second language learning. Studies in Second Language Acquisition, 7, 269-288.

Staehr, J., \& Byrne J. G. (2011). Improving teaching and learning in an information systems subject: A work in progress. Issues in Informing Science and Information Technology, 8, 13-23. Retrieved from http://iisit.org/Vol8/IISITv8p013-023Staehr222.pdf

Sun, Y. (2009). Voice blog: An exploratory study of language learning. Language Learning \& Technology, $13(2), 88-103$.

Thorne, S. L., \& Payne, J. S. (2005). Evolutionary trajectories, Internet-mediated expressions, and language education. CALICO Journal, 22(3), 371-397.

Ushida, E. (2005). The role of students' attitudes and motivation in second language learning in online language courses. CALICO Journal, 23(1), 49-78.

Ushioda, E. (1996) Developing a dynamic concept of L2 motivation. In T. Hickey \& J. Williams (Eds.), Language, education and society in a changing world (pp. 239-245). Dublin/Clevedon: IRAAL/Multilingual Matters.

Ushioda, E. (2008) Motivation and good language learners. In C. Griffiths (Ed.), Lessons from good language learners (pp. 19-34). Cambridge: Cambridge University Press.

Warschauer, M. (2000). Network-based language teaching: Concepts and practice. Cambridge: Cambridge University Press.

Winne, P. H., \& Marx, R. W. (1989). A cognitive-processing analysis of motivation within classroom tasks. In C. Ames \& R. Ames (Eds.), Research on motivation in education: Vol 3. Goals and cognitions (pp. 223-257). San Diego, CA: Academic Press, Inc.

Yates, S. J. (1996). Oral and written linguistic aspects of computer conferencing: A corpus based study. In S. C. Herring (Ed.), Computer-mediated communication: Linguistic, social and cross cultural perspectives (pp. 29-46). Amsterdam and Philadelphia: John Benjamins. 


\section{Appendix A \\ Students' Satisfaction on the Use of Blogs}

Students explicitly agreed on the use of the data obtained in the study for research and dissemination of results.

\begin{tabular}{|c|c|c|c|c|}
\hline & Strongly agree & Quite agree & Agree & Disagree \\
\hline $\begin{array}{l}\text { The level of the task assigned } \\
\text { is appropriate }\end{array}$ & 18 & 12 & 2 & \\
\hline $\begin{array}{l}\text { I have enjoyed dealing with } \\
\text { topics related to my future } \\
\text { career }\end{array}$ & 21 & 8 & 4 & \\
\hline $\begin{array}{l}\text { I have enjoyed authentic } \\
\text { communication }\end{array}$ & 18 & 10 & 4 & \\
\hline $\begin{array}{l}\text { I have enjoyed reflection on } \\
\text { ideas }\end{array}$ & 17 & 12 & 3 & \\
\hline $\begin{array}{l}\text { I have enjoyed giving feed- } \\
\text { back to classmate entries }\end{array}$ & 25 & 7 & & \\
\hline $\begin{array}{l}\text { The assessment of my own } \\
\text { work and peers has been re- } \\
\text { warding }\end{array}$ & 20 & 10 & 2 & \\
\hline $\begin{array}{l}\text { Class discussion has been in- } \\
\text { teresting }\end{array}$ & 26 & 5 & 1 & \\
\hline $\begin{array}{l}\text { Collaborative work has been } \\
\text { productive }\end{array}$ & 22 & 9 & 1 & \\
\hline $\begin{array}{l}\text { The content of the task is in- } \\
\text { teresting }\end{array}$ & 27 & 3 & 2 & \\
\hline $\begin{array}{l}\text { I have enjoyed the writing task } \\
\text { outside the language class }\end{array}$ & 16 & 16 & & \\
\hline Blogs are easy to use & 17 & 8 & 7 & \\
\hline
\end{tabular}

\section{Appendix B \\ Students' Perception on Language Skill Improvement}

\begin{tabular}{|c|c|c|c|c|}
\hline & Strongly agree & Quite agree & Agree & Disagree \\
\hline $\begin{array}{l}\text { My writing fluency has im- } \\
\text { proved }\end{array}$ & 17 & 8 & 7 & \\
\hline $\begin{array}{l}\text { My grammar accuracy has } \\
\text { increased }\end{array}$ & 18 & 9 & 5 & \\
\hline $\begin{array}{l}\text { I know more vocabulary in } \\
\text { English }\end{array}$ & 25 & 6 & 1 & \\
\hline $\begin{array}{l}\text { I know more vocabulary re- } \\
\text { lated to my field }\end{array}$ & 27 & 5 & & \\
\hline $\begin{array}{l}\text { My reading skills have im- } \\
\text { proved }\end{array}$ & 20 & 10 & 2 & \\
\hline $\begin{array}{l}\text { My speaking skills in group } \\
\text { interaction have improved }\end{array}$ & 19 & 10 & 3 & \\
\hline
\end{tabular}




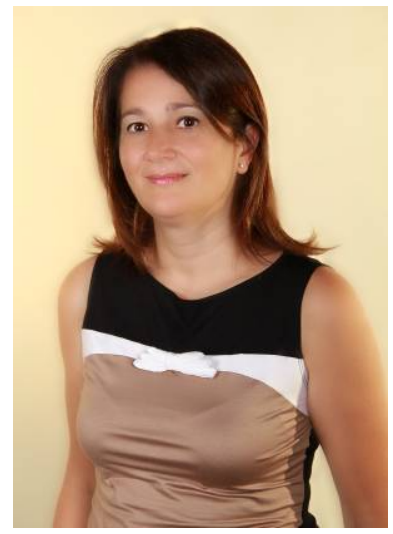

\section{Biographies}

Carmen Pérez-Sabater, $\mathrm{PhD}$, Associate Professor, has been lecturing in English for Computer Science at the Universitat Politècnica de València (Spain), Department of Applied Linguistics, since 1990. She is currently working in the field of Comparative Discourse Analysis, English for Specific/Academic Purposes, Computer-mediated Communication and Gender Studies. Her research has been published in prestigious journals such as Ibérica, Journal of Pragmatics, Linguistik Online, RESLA and Written Communication, among others.

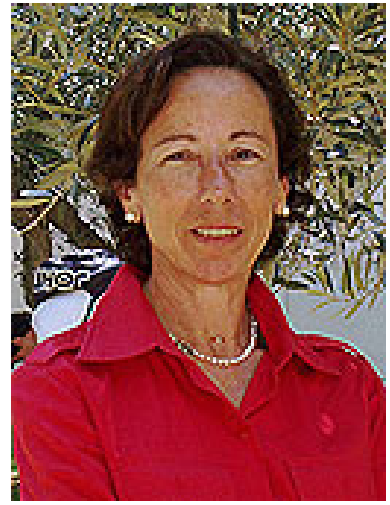

Begoña Montero-Fleta, $\mathrm{PhD}$, is an Associate Professor of English at the Universitat Politècnica de València (Spain), Department of Applied Linguistics. As well as textbooks and material design for English for Academic Purposes, her publications in scholarly journals and international conference presentations have addressed corpus linguisticsbased studies on Comparative Discourse Analysis, Computer-mediated Communication and Terminology. 